\title{
Characteristics of Organophosphate Poisoned Patients Admitted to Emergency Hospital
}

\author{
Osama A. Shabka
}

\begin{tabular}{|c|c|}
\hline & ABSTRACT \\
\hline $\begin{array}{l}\text { KEYWORDS } \\
\text { Organophosphates, } \\
\text { Clinical } \\
\text { Manifestations, } \\
\text { Plasma cholinesterase, }\end{array}$ & $\begin{array}{l}\text { Poisoning with organophosphates is a great health hazard particularly in the } \\
\text { developing countries especially in rural areas. It acts by inhibition of true } \\
\text { cholinesterase and plasma cholinesterase enzymes leading to severe cholinergic } \\
\text { toxidrome. This work was performed to assess demographic and clinical findings of } \\
\text { organophosphates-poisoned cases among patients admitted to Mansoura Emergency } \\
\text { Hospital and to find out the correlation between clinical findings and level of plasma } \\
\text { cholinesterase enzyme. A cross sectional study was done from 3rd march } 2014 \text { to } 1 \mathrm{st} \\
\text { November } 2016 \text { where } 120 \text { organophosphates-poisoned patients were included in the } \\
\text { work. Demographic data, clinical findings and level of plasma cholinesterase were } \\
\text { assessed. The mean age of cases was } 34 \text { years. Female to male ratio was } 1.6: 1 \text {. } \\
\text { Poisoning was more common in married than non-married persons }(78.4 \% \text { and } 21.6 \% \\
\text { respectively). Self-poisoned cases represented } 67.5 \% \text {. No homicidal cases were } \\
\text { recorded. Majority of cases were housewives }(46.6 \%) \text {, farmers }(31.6 \%) \text {, students }(17.5 \\
\text { \%) and shop-keepers }(2.5 \%) \text {. } 76.6 \% \text { of patients were from rural area while urban } \\
\text { cases represented } 23.4 \% \text {. The oral route of exposure represented } 85 \% \text { of patients while } \\
\text { cases exposed to poison through skin contamination and inhalation constituted } 15 \% \text {. } \\
\text { The main clinical manifestations observed were miosis }(91.6 \% \text { of cases). vomiting }(85.8 \\
\text { \%), fasciculations }(56.1 \%) \text {, abdominal colic }(51.6 \%) \text {, generalized weakness }(28.8 \%) \text {, } \\
\text { coma not responding to painful stimuli }(11.6 \%) \text { defecation }(5 \%) \text { and convulsions } \\
\text { (3.3\%). Deceased cases represented } 8.3 \% \text { of patients. A poor correlation was found } \\
\text { between plasma cholinesterase enzyme and clinical findings. }\end{array}$ \\
\hline
\end{tabular}

\section{Introduction}

Poisoning by pesticides is a major health problem particularly among developing countries especially in rural areas (Eddleston et al., 2004). Organophosphates (OP) toxicity represents the most common poisoning among pesticides-poisoned cases (Aardema et al., 2008). Organophosphates acts as strong inhibitor of cholinesterase enzyme which is present in two forms: the first is acetyl cholinesterase that is found in erythrocytes, skeletal muscles and nervous system, while the

\footnotetext{
Osama A. Shabka

Forensic Medicine and Clinical Toxicology Department, Faculty of Medicine, Mansoura University, Egypt.
}

other form is butyryl cholinesterase (PChE) that is present in plasma, liver and heart (Agrawal et al., 2007). Inhibition of these enzymes will lead to accumulation of acetylcholine in central nervous system, muscarinic receptors, autonomic ganglia and myoneural junction. Poisoning by OP may be self-inflicted or accidental, uncommon to be homicidal (Banerjee et al., 2012).

Cases of death reported with OP were mainly attributed to respiratory failure either due to cholinergic crisis or respiratory muscle paralysis (Eddelston et al., 2006). Measuring the level of PChE is used as laboratory evidence for diagnosis of OP poisoning (Banerjee et al., 2012). Some papers reported that estimation of PChE is useful in diagnosis 
of OP poisoning but with no relation to severity of manifestations (Rehiman et al., 2008; Tripathi and Srivastava, 2008). While some authors reported a strong correlation between measurement of enzyme level and severity of manifestations (Devaanur et al., 2013). This cross-sectional work represented an attempt to identify demographic, clinical and laboratory characteristics among OP poisoned patient presented to Mansoura Emergency Hospital and to evaluate the extent of correlation between clinical findings and level of $\mathrm{PChE}$ among these patients.

\section{Subjects and Methods}

A prospective cross sectional study was conducted for one and half-year in Mansoura Emergency Hospital, Egypt. Each patient with history of exposure to OP and manifestations of poisoning was assessed regarding age, sex, occupation, degree of toxicity, level of PChE at time of admission. Exclusion criteria included cases presented more than 5 hours of exposure to poison, hepatic patients, age above 60 years, pregnant women or on contraceptive drug therapy. Informed consent was obtained from competent patient or the legally authorized representatives.

According to Proudfoot classification, patients were classified into 3 groups according to clinical symptoms and signs (Table 1). Severe case is that one associated with either coma not responding to painful stimuli, convulsion, pin point pupil or generalized fasciculation. Moderate case is that one associated with either reactive miosis, generalized weakness or localized fasciculation without severe symptoms. Mild case is that one associated with either vomiting, diaphoresis, abdominal colic or defecation without severe or moderate signs (Proudfoot, 1982).

A blood sample of $5 \mathrm{ml}$ was taken from each patient at time of admission for measurement of pseudocholine-esterase
(PChE) lavel. Lower normal reference level in the kits used is $3500 \mathrm{U} / \mathrm{L}$. Mild reduction of PChE associated with appearance of manifestations occurs when enzyme drops to $20-50 \%$ of its value i.e. $700-1750 \mathrm{U} / \mathrm{L}$, moderate reduction occurs when enzyme is reduced to $10-20 \%$ of its normal value i.e. 350 $-700 \mathrm{U} / \mathrm{L}$, while severe reduction occurs when enzyme is reduced to less than $10 \%$ of its normal value i.e. less than $350 \mathrm{U} / \mathrm{L}$ (Ellenhorn and Barcelox, 1988 and Namba et al., 1971).

\section{Statistical analysis}

Data collected was analyzed in computer by using the Statistical Package for Social Sciences (SPSS) program version 10. Data analysis was done by using descriptive and inferential statistical methods: frequency, percentage, means, standard deviation (SD). A two-tailed $p$-value less than 0.05 was considered to be statistically significant.

\section{Results}

During the period of the study, 120 patients were assessed regarding their demographic data (Table 2) where the mean age of cases was 34 years. Female to male ratio was 1.6:1.Poisoning was more common in married than non-married persons $(78.4 \%$ and $21.6 \%$ respectively). Self-poisoned cases represented $67.5 \%$ while accidental cases constituted $33.5 \%$. No homicidal cases were recorded. Concerning occupation, a $46.6 \%$ of patients were housewives, farmers (31. 6\%) and students $(17.5 \%)$. Cases from rural areas represented $76.6 \%$ of cases while urban patients represented $23.4 \%$.The oral route represented $85 \%$ of cases.

Table (3) illustrated the main clinical manifestations in poisoned cases. They included miosis $(91.6 \%)$, vomiting $(85.8 \%)$, fasciculations (56.1\%), abdominal colic (51.6 $\%$ ), generalized weakness $(28.8 \%)$, coma not 
responding to painful stimuli $(11.6 \%)$, defecation $(5 \%)$ and convulsions $(3.3 \%)$. Death occurred in $8.3 \%$ of patients.

The level of PChE was measured for each manifestation (Figure 1), where the mean level in patients with coma not responding to pain was310 U/L, convulsions (508U/L), generalized fasciculations (1010 U/L), pin point pupil $(950 \mathrm{U} / \mathrm{L})$, reactive miosis
(320U/L), generalized weakness (1106 U/L), local fasciculations (492 U/L), vomiting (822 $\mathrm{U} / \mathrm{L})$, diaphoresis (1001 U/L), abdominal colic ( $945 \mathrm{U} / \mathrm{L}$ ) and defecation ( $321 \mathrm{U} / \mathrm{L}$ ). Mortality was reported in patients with mean enzyme level of $551 \mathrm{U} / \mathrm{L}$. Correlation between manifestations of O.P poisoning and reduction of PChE was assessed using Spearman correlation coefficient.

Table (1): Differentiation between organophosphate cases according to severity of manifestations

\begin{tabular}{|l|l|l|}
\hline \multicolumn{1}{|c|}{ Severe case } & \multicolumn{1}{c|}{ Moderate case } & \multicolumn{1}{c|}{ Mild case } \\
\hline Coma & Reactive miosis & Vomiting \\
Convulsion & General weakness & Diaphoresis \\
Generalized fasciculation & Localized fasciculation & Abdominal colic \\
Pin point pupil & & Defecation \\
\hline
\end{tabular}

Table (2): Demographic data of studied organophosphate poisoned cases $(n=120)$

\begin{tabular}{|l|l|}
\hline \multicolumn{1}{|c|}{ Variables } & \\
\hline Mean age & 34 \\
\hline Sex Number (\%) \\
Male & \\
Female & $46(38.3 \%)$ \\
\hline Marital status & $74(61.7 \%)$ \\
Unmarried & \\
Married & $26(21.6 \%)$ \\
\hline Occupation & $94(78.4 \%)$ \\
Housewives & \\
Farmers & $56(46.6 \%)$ \\
Students & $38(31.6 \%)$ \\
Shopkeepers & $21(17.5 \%)$ \\
Others & $3(2.5 \%)$ \\
\hline Mode of poisoning & $2(1.6 \%)$ \\
Suicidal & \\
Accidental & $81(67.5 \%)$ \\
Homicidal & $39(33.5 \%)$ \\
\hline Rural & None \\
Urban & $92(76.6 \%)$ \\
\hline Route & $28(23.4 \%)$ \\
Oral & \\
Skin and lung & $102(85 \%)$ \\
\hline
\end{tabular}

n: number 
Table (3): Frequency of clinical manifestations in studied cases $(n=120)$

\begin{tabular}{|l|c|}
\hline \multicolumn{1}{|c|}{ Manifestation } & $\%$ \\
\hline Coma & 11.6 \\
\hline Convulsions & 3.3 \\
\hline Generalized fasciculations & 21.6 \\
\hline Pin point pupil & 42.5 \\
\hline Reactive miosis & 49.1 \\
\hline Generalized weakness & 28.8 \\
\hline Local fasciculations & 34.5 \\
\hline Vomiting & 85.8 \\
\hline Diaphoresis & 64.7 \\
\hline Abdominal colic & 51.6 \\
\hline Defecation & 5 \\
\hline Mortality & 8.3 \\
\hline
\end{tabular}

n: number

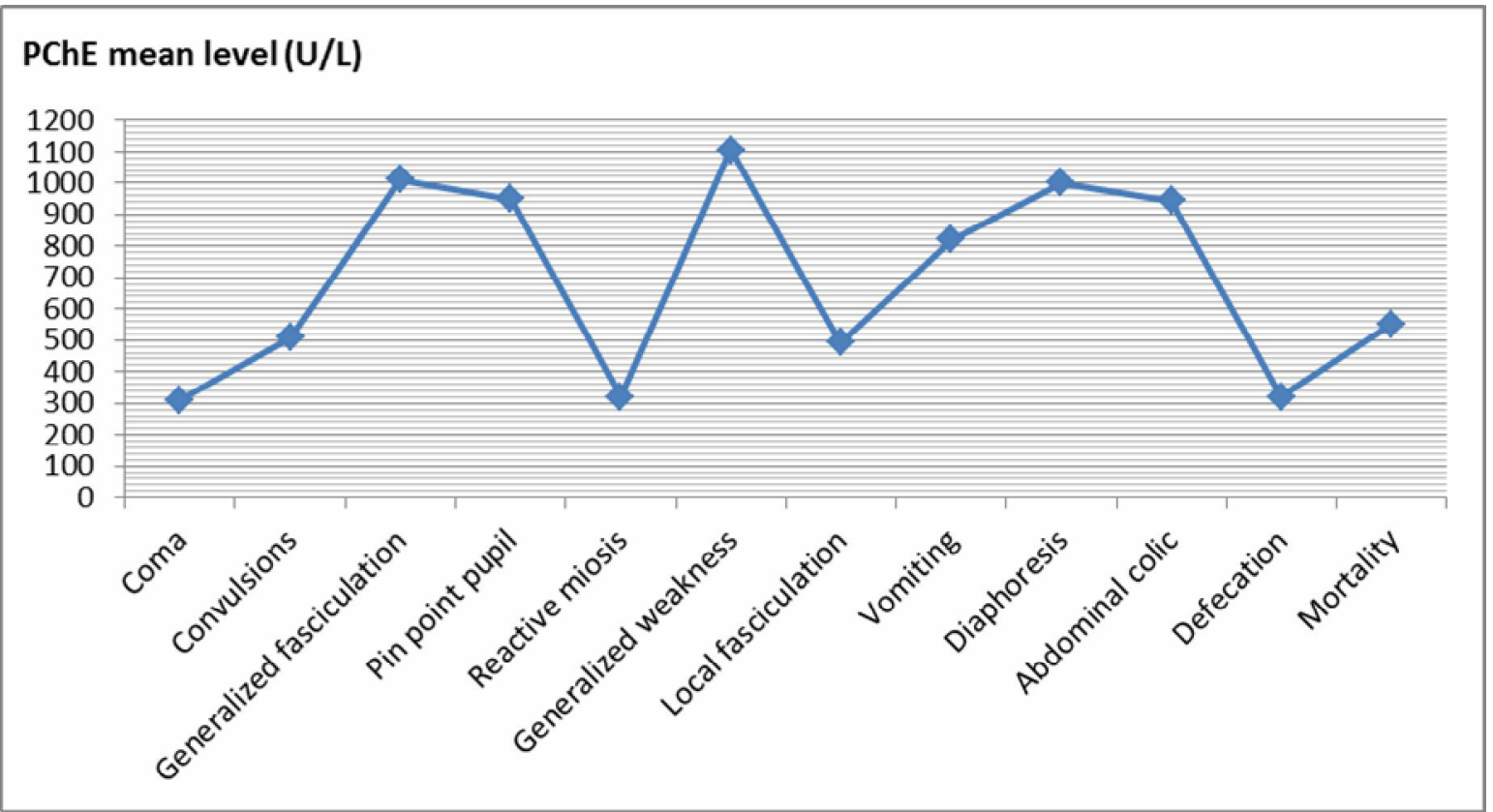

Fig. (1): Mean pseudocholine-esterase (PChE) enzyme levels according to each manifestation of organophosphate poisoning in the studied patients $(n=120)$ 


\section{Discussion}

Poisoning with OP is a great health hazard particularly in the developing countries; it kills millions of people every year particularly in rural areas (Behere, 2008).

In the present work, the mean age of studied cases was 34 years. People at this age are most active physically, mentally and socially so they are more liable to life stress. It was found that $76.6 \%$ of cases were from rural areas owing to wide availability of pesticides used for dusting crops A similar result obtained by Khan et al. (2016) who studied 80 OP poisoned Indian patients where their age range was between 30-44 years. Most of cases were from rural areas. The present finding is in agreement with the studies done by Agrawal et al. (2007) and Bahrash et al. (2010) where most of cases were from rural areas.

The present results revealed that females predominate males where the ratio is 1.6:1. This could be explained by tendency of females to commit suicide by self-poisoning secondary to their emotional liability. Venkateshwarlu et al. (2013) studied 200 OP poisoned Indian cases where 106 cases were females. On the contrary is the result of Khan et al. (2016) who studied 80 Indian OP poisoned patients, where females represented $28 \%$ only, this may be due to variation in religious and social beliefs.

The present study showed that poisoning was more common in married patients $(78.4 \%)$ as they are more liable to domestic, social, financial and occupational problems. In accordance with this result that reported by Khan et al. (2016). They found that $78 \%$ of cases were married. This also explains why the higher percentage of cases was housewives $(46.6 \%)$.

In the present work, farmers represented $31.5 \%$ of poisoned cases. This is due to the fact that poison exposure among farmers occurs mainly during dusting of fields, where pesticides are widely used for agricultural purposes, being accessible and of low cost.

Most of the present studied cases committed suicidal poisoning. This may be attributed to poverty, unemployment, marital problems and stressful life. Similar results were obtained by Venkateshwarlu et al. (2013) where suicidal cases represent the majority of studied Indian poisoned patients.

The commonest route of exposure was oral as most of cases committed suicide by ingesting the poison. No cases due to homicidal poisoning were reported as organophosphates are easily detected due to its characteristic odor and taste.

In the studied patients, the most common sign of poisoning was miosis, while the most common symptom was vomiting. These results are consistent with those obtained by Banerjee et al. (2012) who stated that vomiting and miosis were the commonest clinical findings. Mortality was low (8.3\%) due to early presentation, rapid interference with antidotes. Death was attributed to respiratory failure due to excessive bronchial secretions, bronchospasm and respiratory muscle paralysis. Contradictory to the current finding, Agrawal et al. (2007) reported high mortality in cases who presented late due to delayed interference with supportive measures and antidotal therapy.

In the present work, it was found that manifestations of severe toxicity were associated with only mild or moderate reduction of enzyme. For example, the mean PChE levels were as follows: $508 \mathrm{U} / \mathrm{L}$ with convulsions, $1010 \mathrm{U} / \mathrm{L}$ with generalized fasciculations and 950U/Lin case of miosis. On the other hand, some moderate clinical manifestations were recorded in association with severe reduction of the enzyme. The mean PChE level in relation to reactive miosis 
was $320 \mathrm{U} / \mathrm{L}$, while generalized weakness was associated with mild reduction of the enzyme (mean level $1106 \mathrm{U} / \mathrm{L}$ ). Mortality occurred at mean enzyme level of $551 \mathrm{U} / \mathrm{L}$. Correlation between manifestations of O.P poisoning and reduction of $\mathrm{PChE}$ was assessed using rho Spearman correlation coefficient where $p$ value was greater than 0.05 . This indicates poor correlation between manifestations of O.P poisoning and the reduction of the enzyme, hence the necessity for relying on clinical manifestations and erythrocyte true choline esterase level if possible in establishing degree of toxicity and the proper lines of treatment. PChE should be only used as a marker of exposure to OP and no more.

In consistence with the present findings, Rehiman et al. (2008) stated that the level of PChE and severity of manifestations not always correlate with each other. In addition, Tripathi and Srivastasia (2008) reported that PChE is just a marker of OP poisoning indicating excess absorption of OP. Also, Eddleston et al. (2008) and Worek et al. (2005) stated that PChE enzyme measurement lack sensitivity and specificity and not correlated with severity of manifestations. On the contrary, Devaanur et al. (2013) reported a strong correlation between PChE and severity of manifestations.

\section{Conclusion}

The present work revealed that OP poisoning is more common in females more than males and at mean age 34 years with more predominance in rural areas especially among housewives and farmers. The majority of cases was suicidal followed by accidental poisoning. No homicidal cases were reported. The most common sign was miosis while the most common symptom was vomiting. A poor correlation was found between $\mathrm{PChE}$ level and severity of manifestations of O.P toxicity. So, it is better for the toxicologist to rely on severity of manifestations and the level of erythrocyte true cholinesterase if possible to predict prognosis and determine proper lines of treatment. Hence, PChE can be used only as a marker indicating acute exposure to OP.

\section{Acknowledgment}

Deepest thanks to Prof. Dr. Abd El- Aziz Abu El-Fotouh Ghanem, Professor of Forensic Medicine and Clinical Toxicology, Faculty of Medicine, Mansoura University, for his generous sharing of his experience, continuous help and supply of texts needed to complete this work

\section{References}

Aardema, H.; Meertens, J.; Lightenberg, J.; et al. (2008): "Organophosphorus pesticide poisoning cases and development". Neth. J. Med.; 66 (4): 149-153.

Agrawal, S.B.; Bhatnagar, V.K.; Venkaiah, K.; et al. (2007): "Impairment in clinical indices in acute organophosphorus poisoning patients in India". The Internal Journal of Toxicology; 4:4-5.

Banerjee, I.; Tripathi, S.K.; Roy, A.S. (2012): "Clinic- epidemiological characteristics of patients presenting with organophosphorus poisoning". N. Am. J. Med. Sci., 4(3): 147-150.

Bharath, K.; Guntheti, S.; Shaik, K. (2010): "A study of serum cholinesterase levels in organophosphorous poisoning cases". Journal of the Indian Academy of Forensic Medicine, 32(4):332-335.

Behere, P.B. (2008): "Farmers suicide in Vidarbha region of Maharashtra a myth or reality". Indian J. Psychiatry, 50:124-125. 
Devaanur, R.M.; Mahadeshw, A.P.; Prasanna, S.J. (2013): "Relevance of plasma cholinesterase to clinical findings in acute organophosphorous poisoning". Asia Pacific J. of Med. Toxico., 2(1):23-27.

Eddleston, M.; Buckley, N.A.; Checketts, H.; et al. (2004): "Speed of initial atropinization in significant organophosphorus pesticide poisoning: A systematic comparison of recommended regimens". J. Toxicol., (42):865-875.

Eddeleston, M.; Mohamed, F.; Davies, J.O. (2006): "Respiratory failure in acute organophosphorus pesticide self poisoning”. Q. J. Med., 99:513-522.

Eddleston, M.; Buckley, N.A.; Eyer. P.; et al. (2008): "Management of acute organophosphorus pesticide poisoning". Lancet, 16:371(9612): 597-607.

Ellenhorn, M.J.; Barceloux, D.G. (1988): Chemical disasters. In: Ellenhorn's Medical Toxicology Diagnosis and Treatment of Human Poisoning. Elsevier, P.P. 1067-1108.

Khan, S.; Kumar, S.; Agrawal, S.; Bawankule, S. (2016): "Correlation of serum cholinesterase and serum creatine phosphokinase enzymes with severity and outcome of acute organophosphorus poisoning: a study in rural central India". World Journal of Pharmacy and Pharmaceutical Sciences, 5(4):1365-1373.
Namba, T.; Nolte, C.T.; Jackrel, J; et al. (1971): "Poisoning due to organophosphate insecticides: acute and chronic manifestations". Am. J. Med., 50:475-492.

Proudfoot, A.T. (1982): Organophosphate and carbamate insecticides. In: Diagnosis and Management of Acute Poisoning. $1^{\text {st }}$ ed., Oxford Blackwell Scientific, P.P.153-157.

Rehiman, S.; Lohoni. S.P.; Bhattarai. M.P. (2008): "Correlation of serum cholinesterase level, clinical score at presentation and severity of OP poisoning". J. Nepal Med. Assoc., 47(170):47-52.

Tripathi, A.; Srivastava, U.C. (2008): "Acetylcholinesterase: A versatile enzyme of nervous system". Annals of Neuroscience, 15(4):106-111.

Venkateshwarlu, N.; Gandiah, P.; Prabhaka, K. (2013): "Significance of serum cholinesterase level in patients of OP poisoning". International Journal of Recent Trends in Science and Technology, 9(2):270274.

Worek, F.; Koller, M.; Thiermann, H.; et al. (2005): "Diagnostic aspects of organophosphate poisoning". J. Toxicology, 214(3):182-189. 


\section{خصائص مرضى التسمم بمركبات الفوسفات العضوية الذين تم إدخالهم إلى مستشفى الطوارئ}

\section{أسامة على شبكة}

قسم الطب الثرعي والسموم الإكلينيكية ـ كلية الطب - جامعة المنصورة

يشكل التسمم بمركبات الفوسفات العضوية خطر ا صـحيا كبير ا وخاصـة في البلدان الناميـة وتحديدا في المنـاطق الريفيـة. وهو يعدل عن طريـق تثبط إنزيمسي الكولين استيريز الحقيقي والكولين اسـتيريز المتواجد

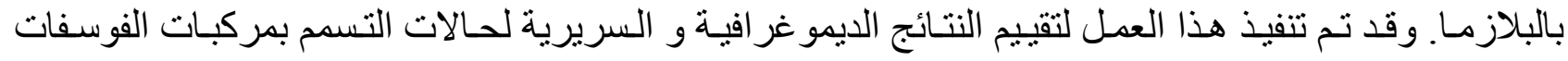

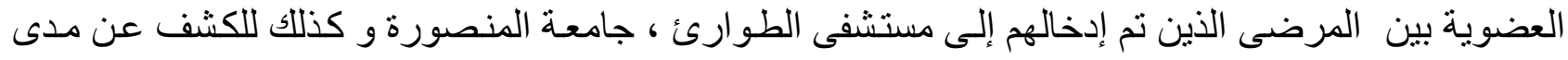

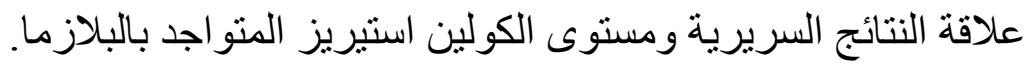

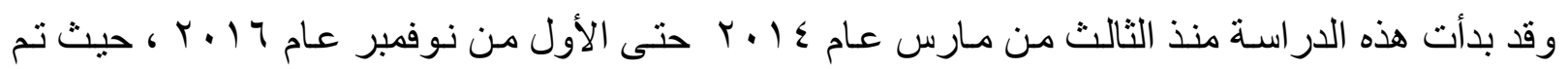
إدر اج • ب ا مـريض تسمح بمركبـات الفوسفات العضوية في العدل و تم تقيهم البيانـات الديمو غر افيـة و النتائج السريرية ومستوى الكولين استيريز بالبلازما.

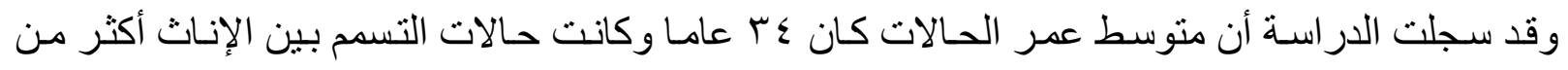
الذكور وبين المتزوجين أكثر من غير المنزوجين وكذلك كان التسمح في معظم الحالات قد تم بغرض الانتحسار

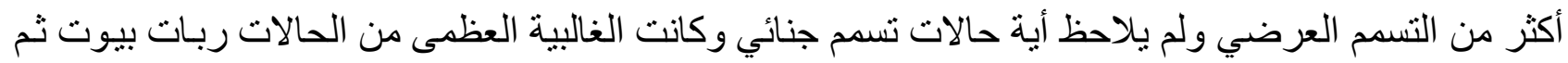
المزار عين ثم الطلاب وكان معظم المرضى من المناطق الريفية

وقد لوحظ أن معظم المرضى كانو ا قد تعرضو ا للمبيد الحثري عن طريق الفم بينما تعرض القليل منهم لـه

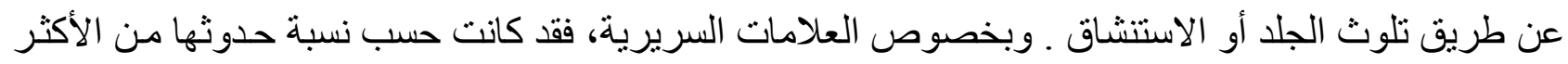
إلى الأقل كالتالي : ضيق بلى بحدقة العين ، قيـُ ، ر رثشه بالعضلات، مغص بالبطن، ضعف عام، غيبوبـة، تغوط ثم تشنجات.

وكانت نسبه حالات الوفاة بين المرضى ؟,^^٪. كما لوحظ مدى ضعف العلاقة بين مستوى إنزيم الكولين استيريز بالبلازما و النتائج السريرية مما يستلزم معه عدم الاعتماد عليه في تقييم تطور أو علاج حالات التسمح

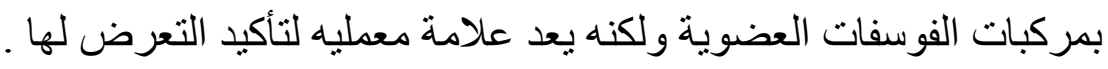

